\title{
In between Language Teaching Methods: Do We Need (to Know About) Methods at All?
}

\author{
Imola Katalin NAGY \\ Sapientia Hungarian University of Transylvania, Cluj-Napoca \\ Faculty of Technical and Human Sciences, Târgu-Mureş \\ Department of Applied Linguistics
}

\begin{abstract}
In this study, we attempt to approach the problem of foreign language teaching from the viewpoint of language pedagogy development in different historical periods: from the grammar translation method through the audio-lingual approaches and up to communicative and postcommunicative methods. We have come today to reconsider the role and status of language teaching not only because globalization has produced an increase in the number of speakers of English all around the world but also due to the fact that the issue of localization (of language teaching methods and techniques) has also come to the fore. This meta-analytical article circumscribes a number of popular methods amongst which teachers can choose, and we also try to summarize the most important foreign language teaching methods that can be spotted in the era of what is presently called the post-method condition.
\end{abstract}

Keywords: language teaching methods, methodology, history of methods, choice between methods, communicative and post-communicative language teaching

\section{Introduction}

The history of the development of language teaching didactics and methodology is a well-documented field of research. In the long history of language teaching didactics, there have been numerous taxonomies regarding trends in language teaching along with different attempts to organize different methods into different categories. For instance, Kumaravadivelu (1994: 29) talks about language-centred methods (e.g. audio-lingualism), learner-centred methods (e.g. communicative methods), and learning-centred methods (e.g. natural approach). Adriana Vizental (2008: 30) operates with the following division: the grammar-translation method (GTM), the audio-lingual approaches (ALA), the communicative approach (CLT), and the post-communicative turn (PCT). Celce-Murcia talks about the following 
major classes of methodologies: cognitive approaches, affective-humanistic approaches, comprehension approaches, and communicative approaches (CelceMurcia 2014: 8).

However, language teaching and learning have a far older history, reaching the ancient world. Language teaching materials and textbooks were written and issued as early as 1272, when Roger Bacon's Greek Grammar appeared. In 1524, Erasmus of Rotterdam wrote his Colloquiorum Libere. In the Middle Ages, Latin and Greek were taught for the purposes of promoting intellectuality and had a major role for higher education (see: Brown 2007, Dağkıran 2015). One of the most important contributors to language pedagogy and a very famous language teacher and methodologist of the $17^{\text {th }}$ century was the Czech scholar and teacher Johann (or Jan) Amos Comenius (originally Jan Amos Komenský), who published plenty of works on the problem of teaching and educating children (e.g. his Didactica Magna completed in 1631 and published in 1657). Language teaching became a scientific discipline in the $19^{\text {th }}$ century, when the bulk of specially designed textbooks and the number of volumes on teaching methodology started to grow.

In this study, we circumscribe a number of popular methods amongst which teachers can choose, and we also try to summarize the most important foreign language teaching methods that can be spotted in the era of what is presently called the post-method condition. We aim to offer a meta-analysis of foreign language teaching methods as they have evolved during different historical periods. We also wish to make a short and synthetic presentation of the most important principles of each of these methods; however, we cannot make a thorough interpretation and/or deep analysis of each as this would exceed the limitations of the present study. We have come today to reconsider the role and status of language teaching not only because globalization has produced an increase in the number of speakers of English all around the world but also due to the fact that the issue of localization (of language teaching methods and techniques) has also come to the fore. We tend to go beyond the frames of a meta-analytical paper and make some experience-based comments only at the end of the article, where we approach the issue of communicative and post-communicative language teaching as these are the approaches that we have experienced more deeply, with their qualities and flaws alike (the description of the principles and techniques and the shortcomings and criticisms we have listed are based on our own personal experience as well). 


\section{The $19^{\text {th }}$ century}

\section{The Grammar Translation Method}

The first well-circumscribed language teaching method was the Grammar Translation Method (GTM), "perhaps best codified in the work of Karl Ploetz (1819-1881), a German scholar who had a tremendous influence on the language teaching profession during his lifetime and afterwards" (Celce-Murcia 2014: 4). The Grammar Translation Method was also called the classical method because it first and foremost focused on the teaching of classical languages. Some of the main principles of the Grammar Translation Method (see: Celce-Murcia 2014: 5, Boyadzhieva 2014: 777-779) are the following:

- The main focus is on morphology and syntax (the forms and inflections of words are learned thoroughly, together with rules and exceptions).

- Focus on written language and sentences rather than texts.

- There is little use of the target language for communication.

- The role of conversation is underestimated.

- The main objective is the study of literary works.

Larsen Freeman states that the most important types of exercises within GMT are the following: translation of literary texts, reading comprehension questions, synonyms and antonyms, deduction of grammar rules, memorization, composition, and building up sentences using certain words (Larsen Freeman 2000: 19-20).

\section{The direct method}

The direct method (DM) appeared as an alternative to grammar translation, and it was described in the works of the French teacher of Latin, François Gouin in 1880. As the Grammar Translation Method focused too much on the written forms of language, the direct method was created as a counterbalance, focusing on oral performance and communication. The direct method received its name from the fact that meaning was conveyed directly in the target language with the help of demonstration and visual aids (Larsen Freeman 2000: 21). Some of the main principles of the direct method (cf. Celce-Murcia 2014: 5, Boyadzhieva 2014: 777-779, Molina et al. 2006: 7) are the following:

- Oral interaction is primary.

- Knowledge of a language is the ability to produce everyday spontaneous speech, which is the first goal of the lessons.

- The most important techniques and procedures are repetitions and drills: questions and answers are the main pathways to reach a gradual oral progression.

- Translation and use of mother tongue are prohibited. 
- Lessons begin with dialogues and anecdotes in modern conversational style.

- Correction is not neglected, putting emphasis on correct pronunciation and grammar.

Thus, the most important techniques are: reading aloud, questions and answers, self-correction, conversation practice, fill-in-the-blanks, dictation, map drawing, and paragraph writing (Larsen Freeman 2000: 31-32).

\section{The reform movement}

The reform movement was another important reaction to GTM and DM, which focused on the teaching of oral language. Although Celce-Murcia (2014: 5) demonstrates that the reform movement was not considered a full-blown pedagogical approach to language teaching, she also highlights that its adherents had a significant influence on certain subsequent approaches. This movement was initiated by the founders of the International Phonetic Association established in 1886. The principles of the International Phonetic Association can be summarized as follows (cf. Molina et al. 2006: 7-8, Celce-Murcia 2014: 5):

- Foreign language study should begin with the spoken language of everyday life as the spoken form of a language is primary.

- Pupils must be familiarized with the sounds of the FL.

- Among the most important procedures, we mention direct techniques with no use of L1: immersion, questions and answers, small groups, and native speakers.

- Examinations take the form of conversations and interviews.

- The findings of phonetics should be applied to language teaching.

- Learners should be given basic phonetic training to establish good speech habits.

\section{The $20^{\text {th }}$ century}

\section{The reading approach}

In the first decades of the twentieth century, the reading approach was devised for English learners in India and German or French learners in the USA. Michael West, who was a teacher of English in India, endorsed the reading approach, in which he recommended graded reading for its practical utility, without neglecting the skill of speaking. Some principles of the reading approach or reading method are (cf. Celce-Murcia 2014: 6, Molina et al. 2006: 10):

- Only the grammar useful for reading comprehension is taught.

- The learner does not have to master the grammar, but merely recognize it. 
- Vocabulary is controlled at first (based on frequency and usefulness) and then expanded (the most basic level was made up of just 300-500 vocabulary items, which led to the introduction of the concept of Basic English, as stated in Ogden 1930).

- Translation is a widely used classroom procedure.

- The first language is used to present reading material, discuss it, and check understanding.

\section{The audio-lingual method}

The audio-lingual approach, or audio-lingual method (ALM) became dominant in the United States during the 1940s, 1950s, and 1960s. Based on the Army Specialized Training Program and emerging from the direct method, the audiolingual method shifted the emphasis from written language to spoken language by developing first and foremost oral skills. "No explanation in or translation into the students' native tongue was allowed in their classes: all instructions had to be given in the target language, and meanings were explained with the help of visuals, realia (real objects), paralanguage and demonstration" (Vizental 2008: 31-32).

Among the most important principles of the audio-lingual method, we mention (as argued in Vizental 2008: 31-32, Celce-Murcia 2014: 7, Boyadzhieva 2014: 777-779, Molina et al. 2006: 12):

- The learner's mother tongue is banned, and target language is used exclusively.

- Vocabulary is severely controlled and limited in the initial stages.

- Full priority of oral skills: vocabulary and grammar are taught in context.

- The importance given to habit formation by using commands to direct behaviour, i.e. students perform actions as indicated by the teacher/other students.

- Grammar is generally viewed as difficult and boring; therefore, theoretical presentations should be avoided (grammatical structures are sequenced and rules are taught inductively).

- Skills are sequenced: listening and speaking are taught first; reading and writing are postponed.

- The usage of technology in language teaching: language laboratories and recordings are widely used.

The most popular audio-lingual techniques are: dialogue memorization, backward build-up (expansion) drills, repetition drills, chain drills, single and multiple substitution slot drills, transformation drills, question and answer drills, dialogue completion, and grammar games (Larsen Freeman 2000: 48-49). 


\section{The audiovisual method}

The audiovisual method appeared in the early sixties in France as the result of the conclusions derived from the CREDIF - Centre de Recherche et d'Étude pour la Diffusion du Français. The most important principles of the audiovisual method are (cf. Molina et al. 2006: 13-14):

- Introducing and promoting basic linguistic varieties (Français fundamental, Basic English).

- Introducing specialized discourses (E.S.P).

- The steps of the lesson are: 1. Presentation: visual scenarios for meaningful utterances and context (using filmstrips and tapes); 2. Explanation: through pointing, demonstrating, selective listening, questions/answers; 3. Repetitions and memorization; 4. Exploitation (development or transposition), visual emancipation, role-play, and new questions and answers; 5. Grammar.

\section{The oral-situational approach}

In Britain, the same historical pressures that fostered the development of the audio-lingual approach gave rise to the oral, or situational approach promoted by Eckersley around 1955 (Celce-Murcia 2014: 7). Among the most important principles of the oral-situational approach, we mention (see: Celce-Murcia 2014: 7, Boyadzhieva 2014: 777-779):

- Organizing structures around situations (e.g. "at the pharmacy", at the post office", "at the bank", "at the restaurant", etc.).

- New words and new grammar items are introduced and practised embedded in situations.

- All language material is practised orally before being presented in written form.

- Only the target language is used in the classroom, and there is little (or no) use of the mother tongue.

- Mainly the most general and useful lexical items are presented.

- Among the most important techniques, drills and repetitions should be highlighted.

\section{The cognitive approach, or cognitive code learning}

Among the most important principles of the cognitive approach, we mention (cf. Celce-Murcia 2014: 7, Boyadzhieva 2014: 777-779, Molina et al. 2006: 18):

- Language learning is viewed as rule acquisition, not as habit formation.

- Lessons are presented deductively (the new structure or item is embedded in a meaningful context; learners are told the rule and given the opportunity 
to apply it to several examples) or inductively (learners are given a number of examples and then told to infer the rule through guided discovery).

- Errors are viewed as inevitable; making mistakes is part of the learning process.

- Vocabulary is taught in context.

- Little use of the mother tongue.

As Molina et al. (2006: 18) notice, the cognitive approach was not a method on its own, rather a reaction against the audio-lingual method.

\section{The affective-humanistic approach and the designer methods}

Building up taxonomies of teaching methods is not an easy task; sometimes there are significant overlaps and the same method is put into different categories by different scholars. Celce-Murcia (2014: 8) states that the term affectivehumanistic approach or the comprehension-based approach covers mainly Krashen's Natural Approach and Asher's Total Physical Response (TPR), whereas Molina et al. (2006: 20-24) consider that the terms affective-humanistic approach and designer methods are fully synonymous, and they include the following: Community Language Learning, The Silent Way, and Suggestopedia. As CelceMurcia (2014) puts it, the so-called designer methods came to the fore in the 1970s and the 1980s (these have been labelled designer methods by Nunan (1989)), and they included more innovative methods such as Total Physical Response (TPR) and Community Language Learning. Some of these methods developed in the twentieth century and expanded in the early twenty-first century as well.

The most important general features of the affective-humanistic approach (a tendency which views language learning as a social and personal process) are the following (cf. Celce-Murcia 2014: 7-8):

- The feelings of students and teachers and the issues of respect and selfrespect are emphasized.

- Students' personal involvement and personal experience should become part of the classroom communication.

- Interactive procedures such as pair and small-group work are widely used (announcing CLT).

- The class atmosphere is more important than materials or methods.

\section{Krashen's Natural Approach}

Krashen's Natural Approach (1983) is also called Krashen's theory of immersion and comprehensible input as it is one of the most important comprehensionbased approaches. It is also known as the Monitor Model (MM) (Boyadzhieva 
2014: 782-783). The most important general features of the Natural Approach are the following (cf. Boyadzhieva 2014: 782-783, Celce-Murcia 2014: 8):

- Listening is the basic skill that will allow speaking, reading, and writing to develop spontaneously over time: learners start to speak only when they feel ready to do so.

- Learners begin with a silent period (they listen to meaningful speech and respond non-verbally in meaningful ways).

- Learners progress by being exposed to meaningful input that is just one step beyond their level of proficiency (finely tuned input).

- Language materials should be as authentic as possible and should come from realia rather than from textbooks.

- Meaning is more important than form and grammar.

- The aim of learning is communication with target-language speakers.

- No use of mother tongue is allowed after the first stages of learning.

- Direct grammar teaching is useless and ineffective (rules only serve students' self-monitoring and self-correction, but they do not foster acquisition or spontaneous use of the target language).

- Error correction is unnecessary and counterproductive: what matters is that the learners can understand and can make themselves understood.

Krashen's Natural Approach became influential in the early 1980s and the 1990s, and it laid the foundations of the communicative approach, or communicative language teaching (CLT).

\section{Total Physical Response}

Total Physical Response (TPR) is a method labelled sometimes a humanistic approach and some other times a designer method. It was introduced by James Asher in the late 1970s. The main features and principles of TPR are the following (cf. Molina et al. 2006: 22, Celce-Murcia 2014: 9, Boyadzhieva 2014: 777-779, Dağkıran 2015: 14):

- Only the target language is used, and no mother tongue is allowed.

- Understanding precedes speaking and active use of language: learners learn from responding to verbal stimulus; they understand the foreign language and respond kinesthetically before starting to speak.

- Language learning should activate the right hemisphere, where the motor centre is located.

- The teacher gives commands and shows learners the meaning by doing the appropriate physical action as a response.

- When learners are ready to speak, they begin to give each other commands.

- Structural language is taught by listening and responding with actions, while grammar is taught implicitly. 
- Learners will learn better if stress to produce language is reduced: activities must be designed to reduce the affective filter.

\section{The Silent Way}

The Silent Way, promoted by Calep Gattegno (in the 1970s) prescribed the use of an array of visuals (e.g. rods of different shapes and colours and charts with words or colour-coded sounds). As a materials developer, Gattegno was influenced by Cuisenaire, who had successfully used coloured charts and wooden sticks to teach mathematics: the Cuisenaire rods. The main features and principles of the Silent Way method are the following (cf. Molina et al. 2006: 27, Celce-Murcia 2014: 9, Boyadzhieva 2014: 777-779, Dağkıran 2015: 14, Larsen Freeman 2000: 69-70):

- The teacher directs the classroom but has an indirect role because he/she has to be silent most of the time. The teacher pronounces each element and asks for their repetition. He/she can use mime to guarantee or check comprehension.

- The language taught is very structural: language is taught in building blocks, but the syllabus is determined by what learners need to communicate.

- No use of deliberately designed textbooks.

- The main focus is on pronunciation.

- Grammar structures and vocabulary are introduced, reviewed, and recycled.

- The materials and techniques used: colour rods and charts. First sounds and then words and sentences are taught through coloured rods of different shapes.

- Drilling is not used.

- The method has an audio-lingual touch as translation is avoided.

- Self-correction and learner autonomy are promoted.

\section{Community Language Learning}

Community Language Learning arises from Rogers's notions of learners in the role of clients and teachers as non-directive counsellors (Molina et al. 2006: 25). The main features and principles of the Community Language Learning method are the following (cf. Molina et al. 2006: 25, Celce-Murcia 2014: 9, Dağkıran 2015: 14):

- Group work has an important role.

- The classroom is organized following a circle or a u-shape (also called horseshoe shape) so that participants can really communicate among themselves. Students sit in a circle or in a u-shape, and they decide what they want to say.

- The teacher translates and gets learners to practice in the target language the material that was elicited. Later, the teacher goes over the words and structures on the blackboard. These interactions are recorded and transcribed by the teacher.

- There is no pre-defined a priori syllabus: students decide what and when to learn according to their needs. 
- The most important procedures are: translation, recording, and analysis techniques.

\section{Suggestology, Suggestopedia, or accelerated learning}

Based on the observation that the ability of acquiring a foreign language is blocked mainly by fear of failure, in the 1970s, Georgi Lozanov came up with a method meant to ensure a relaxing atmosphere in a colourful and decorated classroom with comfortable chairs and accompanied by relaxation music. The main features and principles of the Suggestopedia method are the following (see: Molina et al. 2006: 27, Celce-Murcia 2014: 9, Boyadzhieva 2014: 777-779, Dağkıran 2015: 14):

- The class starts with the relaxation of the students through the appropriate background music, breathing techniques, and voice of the teacher: in a classroom resembling a living room, learners sit in easy chairs and assume a new identity.

- After relaxation, the teacher starts by introducing a script accompanied by music. This way, the teacher introduces the grammar and lexis in a playful manner, using only the target language. During this phase, the students just relax and listen. Students then use the language in a fun and/or undirected way as this is followed by group or choral reading of the script on the first day, along with songs and games.

- Translation is also used to foster comprehension.

- Interactive activities are employed so that learners are able to use what they have unconsciously acquired.

- No correction is performed.

- Dialogues, dramatized texts, songs, and games are widely used.

- No use of the mother tongue is allowed.

- Yoga techniques are used to facilitate relaxation and concentration.

\section{The Communicative Method, or Communicative Language Teaching (CLT)}

The 1970s witnessed the emergence of the communicative approach to language teaching (CLT). The success of CLT is due not only to the changes it involved, as far as methods are concerned, but also to the fact that textbook writers applied its principles quite rapidly. Thus, CLT-based textbooks written and published in Britain spread almost all over the world and turned this method into one of the most influential approaches ever created. The movement was "quickly accepted by language teaching specialists, curriculum developers, and even governments. This provided the impetus for CLT, or the notional-functional approach or functional approach, as it is also termed, to become an international movement" (Molina et al. 2006: 29). 
Communicative Approach is an umbrella term that encompasses a range of closely related methods such as Task-Based Language Teaching (TBLT) or Content and Language Integrated Learning (CLIL). However, some other researchers, such as Rama-Agulló (2012: 182-183), state that TBLT and CLIL are post-communicative trends, whereas Dağkıran (2015:15) states that after the introduction of CLT ContentBased Instruction (CBI) and Task-Based Language Teaching (TBLT) emerged as CLT's successors within the scope of Communicative Approaches (CA). There are several very recent language teaching models which belong to Content-Based Instruction such as: theme-based language instruction (the language curriculum is built around selected topics or themes), sheltered subject matter teaching (carried out in the target language by a content area specialist for a separated class of target language learners), adjunct language instruction (students are enrolled in two courses - a content and a language one - which are mutually coordinated), skillsbased approach (specific subject matter teaching is carried out through the focus on a concrete academic skill area; cf. Molina et al. 2006: 45).

Widdowson (1990: 159), one of the mentors and promoters of CLT, describes it as follows:

It concentrates on getting learners to do things with language, to express concepts and to carry out communicative acts of various kinds. The content of a language course is now defined not in terms of forms, words and sentence patterns, but in terms of concepts, or notions, which such forms are used to express, and the communicative functions which they are used to perform.

By emphasizing language functions, points out Vizental (2008: 39), communicative teaching becomes competency-based (i.e. learners must show what they can do with the help of the language) and task-oriented (i.e. they are taught to perform practical tasks with the help of the language, in situations that simulate or approximate those encountered in real life).

Communicative language teaching relies on the following beliefs and premises (see: Nunan 1991: 279, Vizental 2008: 35-37, Boyadzhieva 2014: 783, CelceMurcia 2014: 8):

- The ultimate aim of foreign language teaching is to develop the learners' communicative competence.

- Learners' own personal experiences must be enhanced as important contributing elements to classroom learning.

- Learning begins with imitation, but the learner has to move on to the stage of free production; otherwise, the process does not turn into actual learning.

- Developing language skills is more important than teaching content. In some cases, the content is academic or job-related material, replicating real-life 
situations (students should use the language functionally and strategically to achieve real-world objectives and goals, the way people do in real life).

- Skills are integrated from the beginning. Teaching aims at developing the four major (macro) skills: reading, writing, speaking, and listening in contentand task-based activities.

- The four skills are divided into two groups: productive (speaking and writing) and perceptive (listening and reading). Perceptive skills facilitate the language input, while the productive skills foster the output.

- Meaning is more important than form or structure.

- Appropriacy of language is as important as linguistic accuracy (as communication takes place in a certain social and discoursal context, and students must be taught to observe social conventions, adapt, and select their language according to the requirements of this social and discoursal background).

- Active participation, personalization, and affective involvement enhance students' learning.

- Spontaneous, improvised practice is more efficient than mechanical repetition. Students work in groups or pairs to transfer and negotiate meaning in real life-like situations.

- Communication is basically interactive, learners must be given a purpose for producing language (simulation, role-play, and debate are efficient classroom procedures for language learning).

- Language must be learned with the help of authentic material.

- The teacher's role is to facilitate communication and only secondarily to correct errors.

- Grammar should be taught only when necessary. No use of mother tongue is allowed in the classroom.

Nevertheless, there are problems associated with CLT. Among these problems, researchers (Kumaradivelu 1994, 2006; Sreehari 2012) highlight its colonial or imperialistic background. The success of CLT is partly due to the rapid spread of textbooks. Every practitioner knows, however, that CLT textbooks have quite a lot of flaws as well; among these, we mention: too many visual aids, which sometimes make pages rather chaotic and disorganized; little emphasis on language accuracy and more on appropriacy; no bilingual wordlists, mini-dictionaries, which are actually needed by learners; cultural aspects are quite out of reach and are often non-familiar, and thus sensitization towards interculturality is often false and artificial; authentic texts are frequently uninteresting, dull and lack relevance from the viewpoint of learners; replication of real-life situations is sometimes awkward. The typical text of the communicative approach is the authentic material (audio, audiovisual, and printed alike). "Perhaps the biggest drawback of using authentic materials is their isolation from the cultural context in which they originally occur" (Siddiqui 2016: 13). Thus, authentic texts are quite often 
random with respect to vocabulary, structures, functions, content, and length, and they are truly useful to learners only if they can relate to them.

Most of the scholars we have mentioned above and practitioners have considered CLT one of the most successful and efficient methods ever implemented. Although in the West CLT started to emerge in the 1970s, and around the 1990s the first critical remarks started to be heard, one must not forget that in Eastern Europe, for instance, CLT penetrated only in the 1990s and is still in vogue these days. What is more, CLT penetrated the teaching methodology of languages other than English some time later. For instance, Bárdos wrote in 2004 that CLT was still the most widespread method which was not being swept away (Bárdos 2004: 70) - although we know that Kumaradivelu's post-method rhetoric had already been heard for at least 10 years by then.

\section{The $21^{\text {st }}$ century}

\section{Current post-communicative paradigm}

A number of new approaches to language learning have appeared in recent years along with criticisms against the concept of method. The first researcher who attempted to challenge the concept of method was Mackey (1965), who considered that the meaning of the word method was obscure and restrictive (see: Dağkıran 2015: 19). Celce-Murcia (2014: 10) presents an overview of the first manifestations against the concept of method and/or against CLT as the best possible method. Thus, she mentions the fact that Strevens (1977: 5) started to articulate criticisms towards various methods in 1977, stating that the complex circumstances of teaching and learning languages (with different kinds of learners, teachers, aims, objectives, approaches, methods, materials, classroom techniques, and standards of achievement) make it impossible that any single method could achieve optimum success in all circumstances.

These trends which have recently emerged have been assigned different names: they are called by Vizental (2008) the post-communicative turn (PCT), but the terms eclectic method (Prahbu 1990), cognitive method (Larsen Freeman 2000), post-method (Kumaradivelu 1994), etc. are also used. Although they cannot be described as a unified theory, the new methods show clearly that teachers have analysed the strengths and weaknesses of the previous approaches thoroughly. Anastasia V. Didenko and Inna L. Pichugova also wonder which term is best: postmethod or post-CLT. They seem to highly appreciate the legacies of CLT (its global and local impact, the notion of competence, the idea of communicativeness, etc.). In spite of this, they signal its weaknesses: for instance, the fact that translation as an exercise type has disappeared almost completely from classrooms. (We daresay 
the ban on translation might be one of the consequences of what Kumaravadivelu (1994) calls the imperialistic or colonial attitudes to language teaching.) Penny Ur (1996: 7) favours the term post-communicative period, but she does not reject post-methodological either since "it is now believed that no single method is optimally effective for teaching languages" (Ur 1996: 7).

Despite the fact that the post-communicative era has generated numerous concepts concerning course designs and teaching procedures, none of them is prevailing and has not turned into a method. "This is the basic reason why the post-communicative period in foreign language teaching is often described as eclectic" (Boyadzhieva 2014: 777-779).

The term eclecticism comes to the fore in the late 1980s and the early 1990s. Prabhu (1990) promotes the concept of eclecticism in an article (There Is No Best Method-Why?), the title of which suggests the basic concern of the author: the lack of a perfect method or a best method, universally applicable and equally efficient in all contexts. The term eclecticism knows a revival in the 2000s, after a period during which the term post-method seemed to be preferred. Dağkıran (2015: 17) makes an analysis of the term principled eclecticism used by Larsen-Freeman (2000) and Mellow (2002). Principled eclecticism can be described as "a desirable, coherent, pluralistic approach to language teaching. Principled eclecticism entails using diverse language learning activities that have different characteristics in response to learner needs" (Larsen-Freeman 2000). As Liu (2004) puts it, the term eclectic method (EM) might not be the best descriptor or denominator as "eclecticism or even principled eclecticism could imply that teachers adopt a varied set of practices based on flexibility and variety of the content" (Liu 2004: 146). Nevertheless, sometimes eclecticism can degenerate into "a methodology without orientation, unsystematic and uncritical, practised by teachers with precarious or poor professional training, incapable of creating an informed eclecticism and who only compile a package of techniques originating in various Methods that do not make sense together. [...] This is to say that eclecticism is still dependent on Method" (Cehan 2014: 28).

Stephen Bax (2003: 278-287) describes an approach which may put an end to CLT, which he names the Context Approach. "This approach disagrees fundamentally with the CLT attitude by arguing that methodology is not the magic solution, that there are many different ways to learn languages, that the context is a crucial determiner of the success or failure of learners" (Bax 2003: 281). Context Approach insists that while methodology is important, it is just one factor in successful language learning.

From 1990 onwards, however, foreign language teaching entered a stage of the post-communicative era, states Boyadzhieva (2014: 784). Based on postmodern and postcolonial ideas, Kumaravadivelu (1994: 27) suggested the deconstruction of the term method and coined the term post-method condition. Kumaradivelu prefers the term post-method to eclectic method due to several 
reasons: "eclecticism at the classroom level invariably degenerates into an unsystematic, unprincipled, and uncritical pedagogy because teachers with very little professional preparation to be eclectic in a principled way have little option but to randomly put together a package of techniques from various methods and label it eclectic" (Kumaravadivelu 1994: 30-31).

Kumaravadivelu's post-method condition aims at providing practitioners with a framework which helps empower teachers with knowledge, skills, and autonomy so that they can tailor for themselves a coherent alternative to method, i.e. more context-situated, teacher-developed methodologies: "the postmethod condition [...] signifies a search for an alternative to method rather than an alternative method" (Kumaravadivelu 1994: 29). According to Kumaravadivelu (1994: 29, 2006: 170-171), the post-method condition emphasizes three features: a) an alternative to the concept of method, b) teacher autonomy and reflection, and c) principled pragmatism, which is different from eclecticism. Principled pragmatism focuses on "how classroom learning can be shaped and managed by teachers as a result of informed teaching and critical appraisal. One of the ways in which teachers can follow principled pragmatism is by developing what Prabhu (1990) calls a sense of plausibility. Teachers' sense of plausibility is their subjective understanding of the teaching they do" (Kumaravadivelu 1994: 30-31).

Kumaravadivelu's post-method theory and the Ten Macrostrategies framework it relies on are inspired by Stern's (1992) Three-Dimensional Framework and Allwright's (2000) Exploratory Practice Framework. This Ten Macrostrategic Framework, proposed by Kumaravadivelu (2001), is shaped by a threedimensional system that consists of three operating principles: particularity, practicality, and possibility.

Many of the principles and techniques of the post-communicative turn have their roots in communicative teaching. The performances of the communicative approach are improved in terms of grammar, writing, literature, cultural issues, and first-language usage. Still, there are other aspects that post-communicative teaching should reconsider. We agree with Swan (1985a, 1985b) and Molina et al. (2006: 32) in the sense that they rightly notice that an excessive focus on appropriacy may obscure "the necessity of teaching lexis, and enough vocabulary, in Swan's opinion, is what the learners need, not appropriacy" (Molina et al. 2006: 32 ). One of the domains which post-communicative or post-method or eclectic pedagogies should re-examine, and perhaps change, is this excessive emphasis put on appropriacy (functions) to the detriment of learning and teaching words. "Functions without lexis are no better than structures without lexis", conclude Molina et al. (2006: 32). We add that teaching functions is important and useful, but functions imply a lot of structures and lexemes of different levels of difficulty. Teachers might find themselves in the position to teach structures which are far beyond the level of students. 
Can (2009: 2) also makes it clear that it is important to have a clear understanding of the distinction between the concept of method and postmethod. The best way of making this clear-cut distinction is to rely on the writings of Kumaravadivelu (1994, 2001, and 2006), the father of the post-method condition. Method is "knowledge-oriented" and can be defined to "consist of a single set of theoretical principles derived from feeder disciplines and a single set of classroom procedures directed at classroom teachers" (Kumaravadivelu 1994: 29), whereas post-method is "classroom-oriented" and refers to the construction of classroom procedures and principles by the teacher himself/herself based on his/her prior and experiential knowledge regarding teaching and his/her own classroom experience. Therefore, post-method is totally different from the existing methods, and it emerged as a result of the limitations of the methods, and hence another method cannot aim to overcome the limitations of the concept of method (Can 2009: 2).

The main features and principles of the post-communicative method/or of the post-method condition are the following (cf. Molina et al. 2006: 27, Celce-Murcia 2014: 9, Boyadzhieva 2014: 777-779, Dağkıran 2015: 14, Erdei 2002: 48, Cadario 2014: 30):

- Learning how to learn is a central element.

- Presenting the forms of grammar and vocabulary: grammar still tends to be taught inductively, but grammar explanations should be based on contrastive and comparative approach.

- Task-based classroom activities; pair and group work, collaborative dialogue between learners, individual work with the use of Internet.

- Reintroduction of mother tongue and translation tasks in the language classroom.

- Use all good and effective teaching practices established in every previous approach that proved to be efficient.

- Return of long-forbidden techniques such as repetition or drilling in case of structures as drills facilitate memorization especially with adult learners.

- Rehabilitation of essay writing, texts about cultural and intercultural issues and literature.

Thus, post-communicative language teaching does not mean noncommunicative language teaching, highlights Erdei (2002: 47). It is rather an ameliorated or superior variant of CLT, more radical, more practical, and more complex, based on the optimization of its deficiencies.

Still, this post-method alternative does not go without criticism, and there are some paradoxes and/or problems that are not solved by post-method/postcommunicative approaches:

- The teaching of phonetics and phonology as part of the oral production are deferred in most textbooks and classroom practices. 
- Spelling is still seen as part of the learner's writing proficiency (see: Boyadzhieva 2014: 787).

- The obvious discrepancy between teaching and testing (testing is always behind teaching; it is far more traditional and reluctant to change).

- The formal, grammatical, and structural aspects are dealt with implicitly, states Erdei (2002: 48), whereas the mediated content is managed explicitly (though other authors stand up for teaching grammar explicitly).

- Without proper teacher education programmes, the post-method condition might entail the risk of ELT practitioners adopting some sort of "my-own method" style (see: Soto 2014).

Molina et al (2016: 37) also name some of the possible future trends in language teaching, which might follow the post-communicative period: the Lexical Approach, based on the concept of the lexical chunk (also termed lexical phrase, holophrase, composite, gambit, prefabricated routine, patterned phrase, frozen form, routine formula, or formulaic expression), i.e. a group of up to eight words that serve as the ideal unit which can be exploited for language learning, Neuro-Linguistic Programming, or NLP, Multiple Intelligence Theory (based on the existence of eight kinds of intelligences which work together: Intrapersonal intelligence, Interpersonal intelligence, Logical-Mathematical intelligence, Linguistic intelligence, Musical intelligence, Spatial intelligence, BodilyKinaesthetic intelligence, and Naturalist intelligence, which may be systematically involved in language lessons to foster language learning), Cooperative Learning (in which students work together in groups to reach common goals), and Bilingual Education Programmes (in which the foreign or second language is used to teach the regular school curriculum). Besides these, they name a few orientations and directions in language learning and teaching such as Language for Specific Purposes (LSP, a movement which prepares learners to fulfil specific professional roles), Immigrant On-Arrival Programmes and Programmes for Students with Limited English Proficiency (SLEP): (which focus on the language which immigrants need to integrate in the receiving country), or Cognitive Academic Language Learning Approach (CALLA, which combines language, content, and learning strategy instruction into the transitional ESL classroom) (Molina et al. 2006: 45).

Boyadzhieva (2014: 785) also mentions some possible future trends in language teaching pedagogy, probably following the post-communicative turn: Content and Language Integrated Learning (CLIL), introducing the idea that any specific content can be learned with the help of a foreign language; Computer Assisted Language Learning (CALL), which focuses on the introduction of the computer in language teaching and learning; Blended Learning, based on the belief that the traditional face-to-face communication in the language classroom must be combined or blended with distant, Internet-mediated learning; Dogme learning, i.e. a topic-based approach focusing on communication, which denies the use 
of course books, claiming that course books tend to focus on grammar and rules and are often culturally biased. Michel Candelier comes up with a novel concept in language pedagogy, i.e. the pluralistic approach to language teaching, based on the idea of plurilingual and pluricultural competence and learners' linguistic repertoires (2008: 4). Nevertheless, we do not aim to describe these trends and directions as they are still part of an ongoing shift in language teaching.

\section{Conclusions}

Post-method pedagogy attempts to validate itself at the expense of previous, past methods, though it is seen by many as a mere search for a method, an attempt to unify procedures in a more holistic way. Post-method pedagogy is, therefore, seen by Bell (2003: 332) not as a true shift or paradigm in language teaching but rather a synthesis of various methods under the umbrella of CLT, or what Liu (1995: 176) calls a method redefining condition. However, neither the postcommunicative approach nor any other previous method can be realized in their purest form in the actual classroom.

Thus, the shift from one method to another resembles somehow the wellknown quarrel of the Ancients and Moderns as progress has always come with an inherent attack on the authority of previously established views and the rise of new trends, which usually claim a great divide from the ancients and challenge their authority by opening fire on their very raison-d'être. The truth is that no new method has ever completely discarded all previous ancient methods. Questioning the authority or efficacy of a method and challenging inquiries in predominant systems is one thing, but changing the paradigm is another, however radical this change of paradigm might seem. There have always been overlaps between different methods. New methods usually try to correct the insufficiencies of previous methods, but they never efface them totally but rather overtake some of their techniques in slightly modified versions.

Nevertheless, we tend to highlight the in-between-ness of the post-method condition as it aims to put an end to the era of well-established methods, but it does not state that post-method era means an era without methods. Kumaravadivelu himself points out this idea when stating that post-method condition does not mean methodlessness; it rather means "that the framework is not conditioned by a single set of theoretical principles or classroom procedures associated with any one particular language teaching method" (Kumaravadivelu 1994: 32). That is why we prefer the term post-communicative period as today's tendencies (be they called post-communicative, post-method, eclectic, etc.) seem to correct the deficiencies of CLT and apply several of its good strategies and techniques rather than replacing CLT totally and irreversibly with something else (whether we call 
it a method or a post-method though the semantics of the term post-method has not been neatly defined and established). Today's language teaching paradigm seems to us to be an improvement of CLT with localized materials and techniques.

Methods are complex constructs with good and bad aspects as well. We also accept that methods are social and often socio-political constructs bearing all the flaws of the societies that create them. But in the practice of teaching what really matters is the way teachers manage (or do not manage) to make the most of the methods they are familiar with. After all, "Methods could be prescriptive, quasipolitical or mercenary (Pennycook 1989), and non-transferable (Nunan 1991), but it all depends on how we look at them. It is the conceptualization of methods that matters" (Liu 2004: 150).

\section{References}

Bárdos Jenő. 2004. Nyelvpedagógiai tanulmányok. Pécs: Iskolakultúra.

Bax, Stephen. 2003. The end of CLT: A context approach to language teaching. ELT Journal 57(3): 278-287.

Bell, David. M. 2003. Method and postmethod: Are they really so incompatible? TESOL Quarterly 37(2): 325-336.

Boyadzhieva, Ellie. 2014. Theory and practice in foreign language teaching Past and Present. Journal of Modern Education Review 4(10): 776-788.

Brown, H. Douglas. 2007. Teaching by principles: An interactive approach to language pedagogy. White Plains, NY: Pearson Education.

Can, Nilüfer. 2009. Post-method pedagogy: Teacher growth behind walls. In: Proceedings of the $10^{\text {th }}$ METU ELT Convention. Ankara. Turkey. Downloaded from: http://dbe.metu.edu.tr/convention/proceedingsweb/Pedagogy.pdf. Retrieved on: 15.03.2019.

Candelier, Michel. 2008. Approches plurielles, didactiques du plurilinguisme : le même et l'autre/Abordări didactice plural ale pluriligvismului: sinele şi altul. Les Cahiers de l'Acedle 5(1).

Cehan, Anca. 2014. In the wake of method. Acta Didactica Napocensia 7(4): 2330.

Erdei, Gyula. 2002. A posztkommunikatív idegennyelv-oktatáshoz [On postcommunicative language teaching]. In: Kárpáti, Eszter-Szúcs, Tibor (eds), Nyelvpedagógia [Language pedagogy]. Pécs: Iskolakultúra. 47-52.

Kumaravadivelu, Bala. 1994. The postmethod condition: (E)merging strategies for second/foreign language teaching. TESOL Quarterly 28: 27-48.

2001. Toward a postmethod pedagogy. TESOL Quarterly 35: 537-560.

2006. Understanding language teaching: From method to postmethod. Mahwah, New Jersey: Lawrence Erlbaum Associates. 
Larsen-Freeman, Diane. 2000. Techniques and principles in language teaching. $2^{\text {nd }}$ edition. Oxford: Oxford University Press.

Liu, Jun. 2004. Methods in the post-methods era. Report on an international survey on language teaching methods. International Journal of English Studies 4(1): 137-152.

Nunan, David 1989. Designing tasks for the communicative classroom. Cambridge: Cambridge University Press.

1991. Language teaching methodology: A textbook for teachers. New York: Prentice-Hall.

Ogden, C. K. (1930): Basic English. A general introduction with rules and grammar. London: Keagan Paul, Trench, Trubner \& Co.

Pennycook, A. 1989. The concept of method, interested knowledge, and the politics of language teaching. TESOL Quarterly 23: 591-615.

Prahbu, N. 1987. Second language pedagogy. Oxford: Oxford University Press. 1990. There is no best method-Why? TESOL Quarterly 24(2): 161-176.

Sreehari, Pusuluri. 2012. Communicative language teaching: Possibilities and problems. English Language Teaching 5(12): 87-93.

Strevens, Peter. 1977. New orientations in the teaching of English. Oxford: Oxford University Press.

Swan, M. 1985a. A critical look at the Communicative Approach (1). ELT Journal 39(1): 2-12.

1985b. A critical look at the Communicative Approach (2). ELT Journal 39(2): 76-87.

Ur, Penny. 1999. A course in language teaching. Cambridge: Cambridge University Press.

Vizental, Adriana. 2008. Metodica predării limbii engleze. Strategies of teaching and testing English as a foreign language. Iaşi: Polirom.

Widdowson, H. G. 1990. Aspects of language teaching. Oxford: Oxford University Press.

\section{Web sources}

Cadario, Elisa. 2014. Eclecticism in the "new" foreign language classroom: Re-thinking practices and developing an awareness of context in teacher training college. In: Banegas, Darío Luis-López-Barrios, Mario-Porto, MelinaSoto, María Alejandra (eds), English language teaching in the post-methods era: Selected papers from the $39^{\text {th }}$ FAAPI Conference, Santiago del Estero: Asociación de Profesores de Inglés de Santiago del Estero. 28-38. Downloaded from: wrap.warwick.ac.uk/.../WRAP_Banegas_SelectedPapersFAAPI2014e.... Retrieved on: 15.03.2019. 
Canale, M.-Swain, M. 1980. Theoretical bases of communicative approaches to second language teaching and testing. Applied Linguistics 1(4): 1-47. http:// dbe.metu.edu.tr/convention/proceedingsweb/proceedings.htm. Retrieved on: 15.03.2019.

Celce-Murcia, Marianne. 2014. An overview of language teaching methods and approaches. In: Marianne, Donna-Marguerite, Ann (eds), Teaching English as a second or foreign language. Boston: National Geographic Learning: Heinle Cengage Learning, Downloaded from: https://ngl.cengage.com/assets/ downloads/tesfl_9781111351694/chapter_1_9781111351694_p03_lores.pdf. Retrieved on: 01.02.2019.

Dağkıran, İpek. 2015. Postmethod pedagogy and reflective practice: Current stance of Turkish EFL teachers. İhsan Doğramacı Bilkent University, Ankara. Downloaded from: http://www.thesis.bilkent.edu.tr/0006997.pdf. Retrieved on: 12.03.2019.

Didenko, Anastasia V.-Pichugova, Inna L. 2016. Post-CLT or Post-Method: Major criticisms of the communicative approach and the definition of the current pedagogy. Web ofConferences 01028. DOI: 10.1051/ SHS 28 shsconf/201628010. RPTSS 2015. https://www.shs-conferences.org/.../shsconf_rptss2016_01028. pdf. Retrieved on: 15.03.2019.

Molina, Gabriel Tejada-Pérez Cañado, María Luisa-Agulló, Gloria Luque. 2006. Current approaches and teaching methods. Bilingual programmes. Downloaded from: https://doksi.hu/get.php?lid=23297. Retrieved on: 10.02.2019.

Rama, José López-Agulló, Gloria Luque. 2012. The role of grammar teaching: From communicative approaches to the Common European Framework of Reference for Languages. Revista de Lingüística y Lenguas Aplicadas 7: 179191. Downloaded from: https://dialnet.unirioja.es/descarga/articulo/4778849. pdf. Retrieved on: 10.02.2019. 